\title{
Mercury levels and genotoxic effect in caimans from tropical ecosystems impacted by gold mining
}

\author{
José Marrugo-Negrete ${ }^{a, *}$, José Durango-Hernández ${ }^{a}$, Clelia Calao-Ramos ${ }^{a}$, \\ Iván Urango-Cárdenas ${ }^{a}$ and Sergi Díez ${ }^{b, *}$ \\ aUniversidad de Córdoba, Carrera 6 No. 76-103, Montería, Córdoba, Colombia \\ ${ }^{\mathrm{b}}$ Environmental Chemistry Department, Institute of Environmental Assessment and Water \\ Research, IDAEA-CSIC, E-08034 Barcelona, Spain.
}

* Corresponding autor:

E-mail address: jmarrugo@correo.unicordoba.edu.co (J.Marrugo-Negrete), sergi.diez@idaea.csic.es (S.Díez) 


\section{Highlights:}

- $\mathrm{Hg}$ in caimans was studied by means of 3 non-lethal tissues that correlate between them

- Higher $\mathrm{Hg}$ were found in tissues of caimans impacted by upstream mining gold sites

- $\mathrm{Hg}$ in scutes and claws are 15- and 8-fold significantly higher than in control

- Caiman shows higher genotoxic damage in blood cells in exposed reptiles vs. controls

- A highly significant correlation was found between $\mathrm{Hg}$ and damage in all the tissues

\section{GRAPHICAL ABSTRACT}

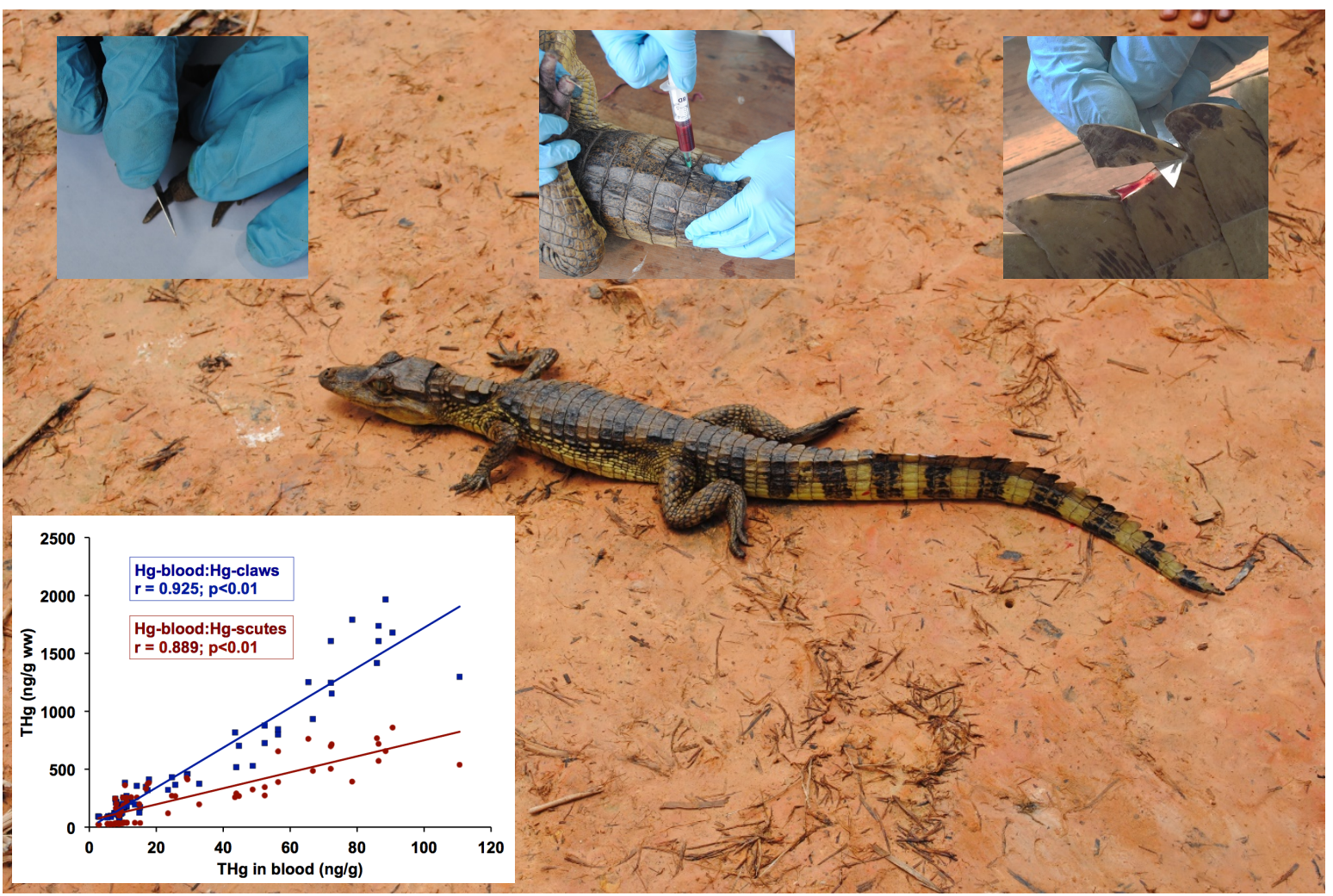




\section{ABSTRACT}

One of the most representative predator species in tropical ecosystems is caiman that can provide relevant information about the impact of mercury $(\mathrm{Hg})$ associated with artisanal and small-scale gold mining. To evaluate the degree to which adverse effects are likely to occur in Caiman crocodilus, total $\mathrm{Hg}$ ( $\mathrm{THg}$ ) concentrations in different tissues and DNA damage in erythrocytes were determined. Samples of claws, scales, and blood were taken from 65 specimens in sites impacted by upstream gold mining, and in a crocodile breeding center as control site, located in a floodplain in northern Colombia. In all the sites, the highest $\mathrm{THg}$ among tissues was in the following order: claws>>scales>blood. High concentrations of $\mathrm{THg}$ were found in the different tissues of the specimens captured in areas impacted by mining activities, with mean values in claws (1100 $\mathrm{ng} / \mathrm{g} \mathrm{ww}$ ), caudal scutes (490 ng/g ww), and blood (65 ng/g ww), and statistically significant differences compared to those of the control site $(p<0.05)$. THg in scutes from impacted sites are 15-fold higher than in control, whereas for claws and blood are 8 times higher, and a high significant correlation with $\mathrm{THg}$ was found in all the tissues. The comet assay reveals significant differences in the DNA damage in the exposed reptiles compared to the controls ( $p>0.05$ ), In sum, C.crocodilus from La Mojana floodplain presents a high ecological risk given its genotypic susceptibility to $\mathrm{Hg}$ levels present in its habitat, which could possibly influence vital functions such as reproduction of the species and the ecological niche that it represents within the ecosystem.

Keywords: Genotoxicity; Caiman crocodilus fuscus; Hg; comet assay; floodplain 


\section{INTRODUCTION}

Due to its release during the artisanal and small-scale gold mining operations, mercury $(\mathrm{Hg})$ contamination has been found in important ecosystems such as natural tropical wetlands, such as La Mojana floodplain in Colombia, where $\mathrm{Hg}$ has been reported in water, plankton, fish, aquatic plants, and sediments (Marrugo et al., 2008a; Marrugo et al., 2010; Olivero et al., 2014; Pinedo-Hernández et al., 2015; Marrugo-Negrete et al., 2015a). Tropical wetlands are the preferred habitat of large reptiles such as alligators and crocodiles, a species that suffers from a population deficit since they are prey of otter and hunting birds when young, and by jaguars when they are adults. Additionally, the pressure exerted by human is a determining factor in the maintenance of the population over time. Moreover, these reptiles are exposed daily to many physical, chemical, and biological agents present in the environment, which in one way or another affect their physiological functions (Ansoar-Rodríguez et al., 2015). Although reptiles have very important functions in ecosystems, they are generally undervalued and poorly documented. These include processes associated with their role as prey, predators, commensals, seed dispersers, pollinators, and other ecosystem services that contribute to the health and integrity of the ecosystem and the energy and matter flow between terrestrial and aquatic environments (Valencia-Aguilar et al., 2013, Urbina-Cardona et al., 2015). As a result, some reptiles are considered good sentinel specimens of the ecosystem health (Böhm et al., 2013), and they are often closely linked to a particular habitat that makes them more vulnerable to habitat degradation compared to birds and mammals (Hopkins, 2000). Although reptiles 
have proven to be excellent sentinel specimens of pollution (Mitchelmore et al., 2006), they remain the least studied group of vertebrates in terms of genetic toxicology. In this sense, evaluation of genotoxicity in wild species employs the comet assay test, as this method is preferred for its sensitivity in detecting DNA damage (Mitchelmore and Chipman, 1998; Carballo and Mudry, 2006). Few studies have applied this method to reptile erythrocytes to determine the degree of DNA damage (Zuñiga et al., 2001; Boned et al., 2011). Among these, Poletta et al. (2011) evaluated the genotoxicity of glyphosate in erythrocytes of Caiman latirostris. Likewise, Schaumburg et al. (2012) studied DNA in reptile species by adjusting the protocols of genotoxicity techniques, including the comet and micronucleus assays, and demonstrated the sensitivity of these biomarkers.

In La Mojana wetland, most of the studies related to contamination from goldmining waste that have been carried out thus far have focused on the ichthyofauna (Marrugo et al., 2008ab; Olivero et al., 2004; Olivero et al., 2014). However, studies conducted on the accumulation of $\mathrm{Hg}$ in Caiman yacare in Brazil showed that this species can be considered an Hg bioaccumulator (Lázaro et al., 2015). We currently lack information regarding $\mathrm{Hg}$ contamination in the species Caiman crocodilus, which, given its role as a predator in controlling the populations of prey species, is one of the main species involved in the maintenance and regulation of aquatic communities in Colombia (Morales-Betancour et al., 2013). For all the above reasons, the main objective of this study was to obtain detailed information on the concentrations and genotoxic effects of $\mathrm{Hg}$ on caimans in order to assess the impact of $\mathrm{Hg}$ in a mining area of Colombia. 


\section{METHODOLOGY}

\subsection{Study area}

The samples for the present study were collected in the Momposina depression located in the north of Colombia (Figure 1), which is considered the most important wetland complex in the country and is characterized as being very productive for its ichthyofauna richness. This wetland complex serves the environmental function of regulating the channels of the Magdalena, Cauca, and San Jorge rivers, dampening floods, and facilitating the decantation and accumulation of their sediments. The source of $\mathrm{Hg}$ in La Mojana floodplain comes mainly from the waste generated by mining activities (INGEOMINAS, 1995; Veiga, 1997; Olivero et al., 2002; Marrugo et al., 2008b) that is transported by these three rivers that cross this region. Specimens of the species Caiman crocodilus fuscus (Cope 1868) were obtained from three sites: La Redonda marsh (S1) and La Encaramada marsh (S2), marked as $\mathrm{Hg}$ contaminated areas, and a crocodile breeding center, located far away from mining activities, that was used as a control site (S3) (Figure 1).

La Redonda marsh (S1), receives mining waste with $\mathrm{Hg}$ directly from an important mining area (mine of Santa Cruz) located in the municipality of Barranco de Loba, south of the department of Bolívar, Colombia. This mining area is one of the larger and most productive auriferous zones in the country, where $\mathrm{Hg}$ is used in great quantities to recover gold using the amalgamation process. THg levels exceeding $30 \mathrm{mg} / \mathrm{kg}$ have been reported in soils close to this mine (Vidal et al., 2010). 
S2 (La Encaramada marsh), despite not having direct discharges from mining activities, is influenced by frequent floods caused by the overflow of the Cauca River that receives mining waste from the northeast of the department of Antioquia and the south of Bolívar that are considered the most important gold mining area in the country (Marrugo et al., 2008b; UPME-MME-UC, 2015; Pinedo et al., 2015). Some studies have shown mercury contamination in this region, with $\mathrm{THg}$ values in marshes sediments ranging from 196 to $1188 \mathrm{ng} / \mathrm{g}$ dry weight, dw. Average percentages of $2.6 \%$ of the bioavailable phase (Marrugo-Negrete et al., 2015b; Pinedo et al., 2015), and mean fish $\mathrm{Hg}$ concentrations were $0.50 \pm 0.10 \mathrm{mg} / \mathrm{kg}$ (Marrugo et al., 2007).

The reference site (S3), is a crocodile breeding center located in the municipality of San Marcos, department of Sucre. The operation of the crocodile breeding center for the species Caiman crocodilus fuscus was established by the Corporation for the Sustainable Development of La Mojana and San Jorge in Resolution number 08262, dated June 4, 2004. This site was chosen as control site because the impact of mining activities is limited to sporadic flooding from the San Jorge River.

Taking into account the hydrological information of the study area, the drought period runs from the end of December to March and early April, whereas the flood period corresponds to the remaining months of the year, with low rainfall in June and November (Pinedo et al., 2015). The climate of the area is hot and humid, and the temperature varies between 28 and $35^{\circ} \mathrm{C}$.

\subsection{Sample collection}


A total of 65 specimens were captured from the locations described above, S1 $(n=23), S 2(n=22)$, and S3 ( $n=20)$, during February and April of 2016 (dry season). Crocodile specimens S1 and S2 were captured at night, with the help of a herpetological lace (Vanzolini and Nelson 1990). Once captured, they were firmly held by the nape and their muzzle was tied with a rubber band. At the control site (S3), the animals were supplied by the breeding center, selecting those reptiles with physiological age similar to those obtained in sampling sites S1 and S2. The reptiles were tied by the neck and immobilized, after which we took the following measurements: the length, measured by taking a tape measure to the back of the animal from the tip of the mouth to the end of the tail; the weight, determined using a clock weight; and the sex, identified by the cloacal examination of the genitals (Cabrera and García, 2004).

The biological tissue samples were collected by cutting the individual caudal scutes, and the claws of the right hind limb with the help of scalpels and pliers, respectively. The samples were packed in polyethylene bags, labeled and stored in a portable fridge at $4{ }^{\circ} \mathrm{C}$ for transport to the laboratory. Peripheral blood samples ( 5 $\mathrm{mL}$ ) were obtained by puncture of the caudal vein under aseptic conditions, according to the technique described by Jacobson (1984), in vacutainer tubes into which we added $\mathrm{K}_{2}$ EDTA for the analysis of $\mathrm{Hg}$ or heparin $(5 \mathrm{~mL})$ for the development of the comet assay technique (Singh et al., 1988). The tubes with the samples were stored in a portable fridge at $4^{\circ} \mathrm{C}$, for their preservation and transport to the laboratory. 
Once the samples were taken, the caimans were released again at the sites where they were captured.

\subsection{Analytical methods}

The determination of total $\mathrm{Hg}$ concentrations in biological samples was performed by atomic absorption spectroscopy using a direct mercury analyzer (DMA80 TRICELL, Milestone Inc., Italy), using EPA method 7473 (USEPA, 2007) by weighting $0.1 \mathrm{~g}$ of blood, $0.02 \mathrm{~g}$ of claws and $0.5 \mathrm{~g}$ of tail scutes samples, respectively. Previous to lyophilization, claws and scutes were washed with abundant distilled water to remove any material adhering to the surface that could affect the analysis. The quantification in the equipment was done using a calibration curve, obtaining a determination coefficient of 0.9997 . The detection limit determined as three times the standard deviation of 10 blank measurements was $0.05 \mathrm{ng} \mathrm{Hg}(0.5 \mathrm{ng} / \mathrm{g} \mathrm{THg}$ for blood and $2.5 \mathrm{ng} / \mathrm{g}$ for claws and scutes) and the method was evaluated by analyzing, in triplicate, certified reference material DORM-2 dogfish muscle from the National Research Council Canada (certified value $=4.6 \pm 0.26 \mu \mathrm{g} / \mathrm{g} \mathrm{dw}$ ), and IAEA-086 human hair from the Community Bureau of Reference (certified value $=0.573 \pm 0.039 \mu \mathrm{g} / \mathrm{g} \mathrm{dw}$ ). The recovery percentage for DORM-2 $(4.52 \pm 0.18 \mu \mathrm{g} / \mathrm{g} \mathrm{dw})$ and IAEA-086 $(0.565 \pm 0.023 \mu \mathrm{g} / \mathrm{g}$ dw) was 98.2 and $98.6 \%$, respectively, with variation coefficients of less than the $5 \%$, within the $95 \%$ confidence limits.

\subsection{Alkaline Comet Assay}


In order to evaluate the appropriate status of the erythrocytes for the application of the assay, cell viability was determined using the Trypan blue dye exclusion method (Tice et al., 2000). A total of 100 cells were counted per sample and the percentage of viable cells was determined.

The alkaline comet assay was carried out as described by Singh et al. (1988), with some modifications following the protocol of Poletta et al. (2008), Schaumburg et al. (2012), and Caliani et al. (2014). Specimen blood was diluted 1:19 (v/v) in RPMl 1640 medium, and, for the positive controls, cells were treated for 30 min with 25 $\mu \mathrm{M} \mathrm{H}_{2} \mathrm{O}_{2}$. Treated cells were used for each electrophoresis instance. A volume of the aforementioned dilution was taken and mixed with $200 \mu \mathrm{L}$ of low melting point agarose. This mixture was distributed on two slides with a previously dehydrated layer of normal melting point agarose that was allowed to solidify at $4 \mathrm{C}$ for $10 \mathrm{~min}$. Afterwards, the slides were submerged in lysis solution for $18 \mathrm{~h}$ in order to break the cell membranes. Subsequently, these slides were incubated in the alkaline electrophoresis solution to allow the unwinding of the double strand of DNA, and electrophoresis conditions were always $300 \mathrm{~mA}$ and $25 \mathrm{~V}(0.90 \mathrm{~V} / \mathrm{cm})$. The whole process was carried out in the dark to avoid any further damage to the DNA.

The slides were washed with neutralizing solution Tris $0.4 \mathrm{M}$. Finally, the samples were stained with ethidium bromide solution $(2 \mu \mathrm{g} / \mathrm{mL})$ and observed in an Olympus BX43F fluorescence microscope equipped with a 505-560 nm excitation filter and a 40x objective in the dark. 100 cells were analyzed per sample (50 from each duplicate). The images were analyzed using the visual scoring method (Collins, 2004) (Figure SI) (reported as Supplementary Information) and classified 
into five categories of damage according to the fragments migration (length of the tail): Class 0 , no damage, no fragments migration (no tail); Class 1, slight damage (tail length less than nucleus diameter); Class 2, moderate damage (length of the tail greater than a nucleus diameter but less than diameter of two); Class 3 , high damage (tail of length greater than the diameter of two nucleus and less than of three); and Class 4, extremely high damage (tail length greater than the diameter of three nucleus).

Comets were individually scored according to class, and the results were expressed as DNA damage index comet assay (DICA) according to: DICA $=\mathrm{n} 1+2$ $n 2+3 n 3+4 n 4$, where $n 1, n 2, n 3$ and $n 4$ is the number of cells in damage category 1, 2, 3 and 4, respectively (Rodríguez-Ferreiro et al., 2002). Hence, DICA ranged from 0 (completely undamaged: 100 cells $\times 0$ ) to 400 (maximum damage: 100 cells $\times 4)($ Collins et al., 2008).

\subsection{Statistical analysis}

The results of THg concentrations in the different tissues are presented as the mean $\pm S D$, in wet weight $(w w)$. The results did not meet the normality and homoscedasticity tests of Shapiro-Wilk and Bartlett, respectively; therefore, nonparametric statistics were used as a data analysis tool. The Kruskal-Wallis test was used to evaluate significant differences in THg and DICA in different tissues and sampling sites, using multiple comparisons through the Mann-Whitney test. Likewise, Kruskal-Wallis test was used to evaluate differences in the weights and lengths of the captured specimens, while the Mann-Whitney test was used to analyze variation in $\mathrm{THg}$ concentrations in the studied tissues relative to sex. A 
Spearman's correlation analysis ( $r$ ) was performed in order to determine correlations between the THg concentrations in tissues, DICA, and the size of the animal. The analyses were performed using the statistical program IBM SPSS Statistics Version 23.0.0.0, at a significance level of $p \leq 0.05$.

\section{RESULTS AND DISCUSSION}

\subsection{Concentrations of $\mathrm{THg}$ in different tissues}

The number of specimens, length, weight, sex, and THg concentrations at each of the sampling sites are shown in Table 1. The number of female specimens was higher than the number of males at all the sampling sites except for the control site. Nevertheless, no statistically significant differences were found in the $\mathrm{THg}$ concentrations of the different tissues between males and females $(p>0.05)$, and therefore, sex was not considered for any statistical analysis. Several studies have found no significant mean differences by gender, in tissues of reptiles of the order Crocodilia (Jagoe et al., 1998; Schneider et al., 2012; Lázaro et al., 2015; Nilsen et al., 2016). The length of the specimens captured was between 50 and $68 \mathrm{~cm}$, with a single individual exceeding $80 \mathrm{~cm}$. Given the small variation in size between specimens, which may indicate the same chronological age, these lengths correspond to those of juvenile reptiles (Rodríguez 1989; Buenfil-Rojas et al., 2015). Moreover, individuals in this life stage are characterized by their high metabolism and assimilation of environmental pollutants (Kant and Tansel, 2000). 
As expected due to standardization of animal sizes, no statistically significant differences were found for weight and length of the captured specimens among the three sampling sites $(p>0.05)$. Similarly, no significant correlation was found between the $\mathrm{THg}$ concentrations in the tissues and the size or weight of crocodilians at the different sampling sites $(\rho<0.1 ; p>0.05)$. Several studies have found a positive relationship between the $\mathrm{THg}$ concentration in tissues such as muscle, scales, blood, and claws and the size of Alligator mississippiensis, Melanosuchus niger, and Caiman crocodilus (Yanochko et al., 1997; Burger et al., 2000; Schneider et al., 2012, 2015; Lázaro et al., 2015; Nilsen et al., 2016). However, other studies on Crocodylus moreletii and Crocodylus acutus have found a different pattern (Rainwater et al., 2002). This discrepancy can be explained by ontogenetic variation and habitat-related variation in the diet, which determine individual and inter-species differences, especially in blood that indicates recent toxic exposure (Lázaro et al., 2015; Buenfil-Rojas et al., 2015).

Highest THg concentrations were found in claws, followed by scutes and blood (Table 1). Similar findings were previously reported in other species of alligators and caimans (Lázaro et al., 2015; Schneider et al., 2015; Buenfil-Rojas et al., 2018). Moreover, the highest $\mathrm{THg}$ in all the biological samples correspond to samples located at $\mathrm{S} 1$. THg concentrations were about 18 times higher in claws than in blood in all three sampling sites. Statistical analysis (i.e. Kruskal-Wallis test) shows significant differences in $\mathrm{THg}$ for the three tissues $(\mathrm{H}(2, \mathrm{~N}=60,69$ and 66$)=$ $52.4619,45.4090$ and 51.4297 ) for $S 3, S 2$, and $S 1$, respectively, with $p<0.001$ ) in all sites. Multiple comparisons using the Mann-Whitney test indicate that the mean 
$\mathrm{THg}$ in biological samples was significantly different among all tissues, except between claws and scales at S2. Weight and length in crocodilians were tested and showed colinearity $\left(r^{2}=0.935 ; p<0.01\right)$; however, no relationships were found between THg in any tissue and the length, probably due to the low variation in size in the collected juvenile crocodilians $(\mathrm{N}=65$; mean length $=58 \pm 4 \mathrm{~cm})$.

The highest concentrations of THg found in the claws and scales versus blood are related to its high content of $\beta$-keratin. This protein is rich in amino acids with sulfhydryl groups that form complexes with $\mathrm{Hg}$ of the metallothioneins type, facilitating the toxic bioconcentration of $\mathrm{Hg}$. In fact, these tissues have shown a high potential for serving as a better indicator of contaminant levels in internal tissues than muscle and bone (Buenfil-Rojas et al., 2018; Schneider et al., 2015). On the other hand, in the caudal scutes of crocodiles, the content of $\mathrm{THg}$ in the keratinized epidermis can be diluted by the bone dermis of the scales (Schneider et al., 2015); in addition to the losses due to the natural erosion of the skin, and the effect that dietary changes have on the THg concentration in both blood and scales, due to continuous metabolic exchange with the rest of the body (Rainwater et al., 2007; Richardson et al., 2002; Nilsen et al., 2016). These physiological differences could explain the differences in THg concentrations between blood, scutes, and claws. Similarly, several studies have reported that claws are better contamination biomonitors due to their ability to store information over time, and to their lack of susceptibility to dietary variations in $\mathrm{Hg}$, because they act as sinks for nutrients and other dietary materials (Hopkins, 2007; Lázaro et al., 2015). Blood, 
meanwhile, has been reported as an indicative of recent exposure, as it acts as a means of transporting the contaminant to all tissues (Khan and Tansel, 2000).

A significantly correlation was found between the different tissues evaluated at the three sampling sites (Figure 2), suggesting a high positive relationship among blood vs. scutes $(r=0.889 ; p<0.01)$ and blood vs. claws $(r=0.925 p<0.01)$. Also, THg in scutes and claws were significantly related $(r=0.924 p<0.01)$. As has been described previously (Schneider et al., 2015), keratin is a better predictor of exposure to $\mathrm{Hg}$ than muscle and bone tissues. Even though muscle tissues have been traditionally used to monitor $\mathrm{Hg}$ concentrations in the environment, the high affinity of $\mathrm{Hg}$ to keratin (because the prevalence in keratin of the sulfur-containing amino acid cysteine), better reflects $\mathrm{Hg}$ exposure over time. Some researchers identify the bloodstream as a possible route of distribution of toxic substances such as $\mathrm{Hg}$, being $\mathrm{Hg}$ in blood directly related to the body burden of $\mathrm{Hg}$ in organisms, and when the exposure is recurrent, it becomes a persistent body burden (Burger et al., 2005; Buenfil-Rojas et al., 2015).

The presence of high concentrations of $\mathrm{THg}$ in cocodriles is a cause of great concern, because of species preservation, and for public health risk, because many villagers often consume them as a source of meat. Several studies have indicated that high concentrations of $\mathrm{Hg}$ in animals can alter the endocrine system by inhibiting the action or normal functioning of hormones, given the ability of methylmercury to bind sulfhydryl groups and the formation of $\mathrm{Hg}$ complexes with selenium-enzymes in the pituitary and thyroid gland, which interferes with the synthesis, secretion, transport, action, or elimination of natural hormones in the 
body that are responsible for processes such as homeostasis, reproduction, development, and behavior (Schneider et al., 2012; Meyer et al., 2014). Besides this, C.crocodilus fuscus is in category II of CITES (Convention on International Trade in Endangered Species of Wild Fauna and Flora), and hunting has been the primary reason for population decline in Colombia, as it is a target of illegal trafficking to commercialize its skin. The database analysis of the regional autonomous corporations shows that $99 \%$ of seizures belong to this subspecies (Morales-Betancourt et al., 2013). C.crocodilus is part of a family of long-lived reptiles, and this longevity could pose a risk in terms of $\mathrm{Hg}$ toxicity, because the animals live in aquatic habitats, such as wetlands and marshes, where the production of toxic methylmercury is high (around 10\%), and they also feed on invertebrates and higher order fish, accumulating $\mathrm{Hg}$ in their tissues for years (Meyer et al., 2014). Finally, this accumulated $\mathrm{Hg}$ can, in turn, be consumed by the inhabitants of the region, given the high hunting rate of this species and its incorporation into the natives' diet (De la Ossa \& De la Ossa-Lacayo, 2011; De la Ossa-Lacayo \& De la Ossa, 2012).

\subsection{Spatial variability}

The results show higher concentrations of $\mathrm{Hg}$ in $\mathrm{S} 1$, followed by $\mathrm{S} 2$, and finally $\mathrm{S} 3$ (control), for all the evaluated tissues (Table 1). Average THg in the control S3 for blood and claws is about 2 and 8 times lower than in S2 and S1, respectively. In the case of the scales, 15- and 8-fold higher concentrations are observed in the specimens captured in $\mathrm{S} 1$ and $\mathrm{S} 2$ compared to those at the control site, respectively. Statistically significant differences were found between the means of 
THg concentrations for the three sampling sites in all the evaluated matrices ( $p$ $<0.01)$, except between the captured specimens at S3 and S2 for blood ( $p=0.097)$. The highest concentrations of $\mathrm{THg}$ found in C. crocodilian are from the specimens located at S1 (La Redonda marsh), that should be attributed to the fact that this site receives wastes generated by the upstream gold mining activities of the Santa Cruz mine district, directly related with $\mathrm{Hg}$. In fact, the mining district of Santa Cruz is a site considered a 'hotspot' site of Hg contamination in Colombia (Vidal et al., 2010; Perez-Vargas et al., 2014; UPME-MME-UC, 2015; UPME-MME-UC, 2016). Several studies report high $\mathrm{Hg}$ concentrations in domestic animals, plants, and soils in this area (Argumedo et al., 2013; Perez-Vargas et al. (2014). Moreover, some authors have reported values similar to those found in this study at sites in the Brazilian Amazon that have been highly contaminated with $\mathrm{Hg}$ by mining activities, with values of $2176 \pm 725 \mathrm{ng} / \mathrm{g} \mathrm{ww}$ and $387 \pm 136 \mathrm{ng} / \mathrm{g} \mathrm{ww}$ in claws and scales, respectively, for C.yacaré (Lazaro et al., 2015), and values of $348 \pm 298$ ng/g ww (range 70-770) and $205 \pm 158 \mathrm{ng} / \mathrm{g}$ ww (range 70-570) in scales of C.crocodilus and M.niger, respectively (Schneider et al., 2015). Nonetheless these values are lower than those found in the Florida Everglades for juvenile alligators, with values of $5830 \pm 104 \mathrm{ng} / \mathrm{g}$ and $160-680 \mathrm{ng} / \mathrm{g}$ for blood and scales, respectively (Khan and Tansel, 2000; Nilsen et al., 2016). On the other hand, in sites with low Hg contamination in Central America, like Belize and Costa Rica, values up to 100 $\mathrm{ng} / \mathrm{g}$ in the scales of Crocodylus acutus and Crocodylus moreletii have been reported (Rainwater et al., 2007; Tellez et al., 2017). 
Despite the controlled living conditions present in the crocodile breeding center, the low $\mathrm{THg}$ concentrations found in the three tissues evaluated in the control species (S3) can be linked to the composition of the food products and/or $\mathrm{Hg}$ depositions (dry and humid) transported by air from the mining area.

According to our results, claws, scales, and blood of C.crocodilus fuscus can be used as good target tissues to assess both levels and spatial patterns of $\mathrm{Hg}$. Among them, the preferred tissue is claw, since it is a less invasive tissue to analyze $\mathrm{Hg}$ concentrations in caimans in comparison with scutes and blood. Although all could be used as precision tools in the spatial analysis of $\mathrm{Hg}$ exposure, some of these tissues are susceptible to the ontogenetic and dietary variations of the animals and represent the time-integrated $\mathrm{Hg}$ exposure in their habitat (Lazaro et al., 2015). In fact, it has been reported that $\mathrm{Hg}$ concentrations in crocodiles can vary considerably between sites (Jagoe et al., 1998).

The results of this study remarkably show the effect of mercury-contaminated ecosystems on fauna. In this case, it is shown how the natural wetland system, which receives $\mathrm{Hg}$ wastes from gold mining activities, possibly promotes methylation conditions of toxic materials (given the anoxic conditions prevailing during periods of flooding and the high load of organic matter in sediments), and favors the uptake of $\mathrm{Hg}$ in the body burden of $\mathrm{C}$. crocodilus fuscus through bioaccumulation and biomagnification processes. Once again, this study demonstrated the problems related with artisanal and small-scale gold mining, by showing significant differences between sites affected by different degree of $\mathrm{Hg}$ contamination. 
Similarities with other studies are difficult to draw because of different studied species as well as the particular characteristics of every environment. Table 2 shows recent studies on different alligators and caimans. In general, $\mathrm{Hg}$ concentrations found in biological tissues claws of our specimens was similar or even lower than those that have previously been reported.

\subsection{Comet Assay}

Assessing the genotoxicity of wildlife species is a tool to document how exposure to xenobiotics can affect the health and condition of natural populations (Carballo and Mudry, 2006). The comet assay has been applied to multiple wild species to detect DNA damage, and this technique has also proven to be a sensitive method for the detection of the genotoxicity of chemicals and complex mixtures, as well as a method for environmental biomonitoring (Ansoar-Rodríguez et al., 2015). Among the wild species that have been used to assess DNA damage from environmental contaminants are the reptiles. Several studies showing a high sensitivity in these species for detecting the effects of genotoxic agents (Poletta et al., 2009; StrunjakPerovic et al., 2010; Poletta et al., 2011; Zapata et al. 2016). Among them, Zapata et al. (2016) reported evidence of genotoxic effects on the species Trachemys callirostris in the Magdalena and Sinú river basins, that is close to our study sites..

In our comet assay, the cell viability was in the range of 95 to $100 \%$ for all the analyzed samples, indicating that all blood samples were in good condition for the assay. Therefore, the comet assay was carried out in order to evaluate the toxicological susceptibility of $C$. crocodilus in La Mojana floodplain. 
Results show that a significant increase in DNA damage was found in crocodilians at $\mathrm{S} 1$ and $\mathrm{S} 2$ compared to the control site, S3 (Figure 3). It can be observed that the greatest damage to DNA occurred in the specimens collected in S1, compared to S2 and S3. We found significant differences between the mean values of DICA in these sampling sites $(p<0.01)$. On the other hand, no correlation was found between DICA values and the length or weight of the animals. Again, this finding allows us to argue that the homogeneity in sizes of the captured specimens does not allow us to draw any conclusion regarding the time of exposure, as evaluated through toxic exposure at different life stages of the animal.

Finally, relationships between DICA and THg concentrations in the biological tissues were evaluated for the specimens at each of the sampling sites, and for the total of the specimens. A highly significant correlation was found between the concentrations of THg in all the tissues and DICA when we evaluated all analyzed specimens together $(\rho=0.878, p=0.00 ; \rho=0.813, p=0.00 ; \rho=0.633, p=0.00$; for blood, claw, and scale, respectively) that shows that the degree of exposure to $\mathrm{Hg}$ by $C$. crocodilus fuscus has a high influence on genomic alterations presented by these organisms. On the other hand, S1 showed a high correlation in all the tissues in relation to DICA, whereas S2 only showed a correlation with blood $(\rho=0.829$, $\mathrm{p}=0.001)$. This finding suggests that a continuous and recent exposure to $\mathrm{Hg}$ occurs in crocodilians living near these areas, especially those surrounding the mining district that is considered a hotspot site (UPME-MME-UC, 2015). According to Nilsen et al. (2016), high $\mathrm{Hg}$ exposure of the C. crocodilus fuscus in this area could potentially indicate a decrease in overall DNA methylation. According to this 
supposition, this scenario could have very serious consequences for the species, because DNA methylation, which consists in the covalent addition of a methyl group to the carbon 5 of the cytosine, is an epigenetic modification that allows functions that include gene expression regulation, the promotion of chromosomal stability, and the silencing of transposon transcription (Di Giacomo et al., 2013, Parrott et al., 2014, Rodríguez et al., 2006). In addition, Hg causes reproductive and neurological deterioration as a function of direct exposure (Crump and Trudeau, 2009; Frederick and Jayasena, 2011; Khan and Tansel, 2000) that can contribute to population decline and species loss.

\section{CONCLUSIONS}

C.crocodilus living in the aquatic ecosystems of La Mojana floodplain, allows us to demonstrate its usefulness as a potential sentinel species for assessing bioaccumulation of $\mathrm{Hg}$. In fact, THg concentrations of different biological tissues (blood, claws, and scales) showed high Hg concentrations that are higher in those animals captured on sites receiving wastes generated by the upstream gold mining activities that use $\mathrm{Hg}$.

One important finding was that claws, scutes, and blood provided useful information about the $\mathrm{Hg}$ exposure of crocodilians, since they are significantly correlated. In fact, all tissues were found to be suitable as non-lethal predictor for measuring $\mathrm{Hg}$ bioaccumulation in reptiles. Results proved that among the three 
non-lethal methods employed, claws seem to be the best predictor, because these provide the same information, and is even less invasive than scutes and blood.

According to the comet assay to detect DNA damage, there is a statistical difference between DICA of crocodilians impacted by upstream artisanal and small-scale gold mining operations in comparison with control site. Moreover, a highly significant correlation was obtained between DICA and THg in all biological tissues. This fact confirms an environmental impact downstream from mining districts, with toxic effects that probably cannot be limited to the evaluated animals, but likely extend to the rest of the species that inhabit these ecosystems, and further indicating the potential risk to the human inhabitants who consume their meat.

\section{ACKNOWLEDGEMENTS}

The authors wish to thank the Colombian Institute for the Development of Science and Technology "Francisco José de Caldas" (COLCIENCIAS) for the financing of the project: Spatial distribution of heavy metals and nutrients in flooded soils of the Mojana region: environmental implications and Recovery strategies, identified with the code: $1112-569-35214$. 


\section{REFERENCES}

Ansoar-Rodríguez, Y., Carmem S. Fontanetti, and Cintya A. Christofoletti. 2015

"Aplicaciones del Ensayo Cometa en Genética Ecotoxicológica." Revista CENIC Ciencias Biológicas 46.1 (2015): 51-62.

Argumedo-Garcia, M., Consuegra-Solórzano, A., Vidal-Durango, J., MarrugoNegrete, J. 2013. Exposición a mercurio en habitantes del municipio de San Marcos (Departamento de Sucre) debida a la ingesta de arroz (Oryza sativa) contaminado. Rev. Salud pública, Volumen 15, Número 6, p. 903-915.

Böhm, M., Collen, B., Baillie, J.E.M., Bowles, P., Chanson, J., Cox, N., Hammerson, G., et al., 2013. The conservation status of the world's reptiles. Biological Conservation. 157, 372-385.

Boned, M., Lopez Gonzalez, E., Latorre, M., Poletta, G., Siroski, P. 2011. Determinacio'n del valor basal de micronu' cleos $(\mathrm{MN})$ en la tortuga de laguna (Phrynops hilarii). J. Basic Appl. Genet. 40, 91.

Buenfil-Rojas, A. M., Alvarez-Legorreta, T., \& Cedeño-Vázquez, J. R. 2018. Mercury and metallothioneins in blood fractions and tissues of captive Morelet's crocodiles in Quintana Roo, Mexico. Chemosphere, 199, 630-636.

Buenfil-Rojas, A.M., Alvarez-Legorreta, T., Cedeño-Vazquez, J.R., 2015. Metals and metallothioneins in Morelet's crocodile (Crocodylus moreletii) from a 
transboundary river between Mexico and Belize. Arch. Environ. Contam. Toxicol. 68 (2), 265-273.

Burger J, Campbell KR, Campbell TS, Shukla T, Jeitner C, Gochfeld M. 2005. The use of skin and blood as non-destructive indicators of heavy metal contamination in northern water snakes (Nerodia sipedon). Archiv Environ Contam Toxicol;49:232238.

Burger, J., Gochfeld, M., Rooney, A.A., Orlando, E.F., Woodward, A.R., Guillette Jr., L.J., 2000. Metals and metalloids in tissues of american alligators in three Florida lakes. Arch. Environ. Contam. Toxicol. 38 (4), 501-508.

Cabrera F., Garcia G. 2004. Anatomical Characteristics of the Male Genital Tract of the ract of the Caiman crocodilus crocodilus, Rev. Fac. Cs. Vets. - UCV. 45 (2): 55-63.

Caliani, L., Campani, T., Giannetti, M., Marsili, L., Casini, S., Fossi, M. 2014. First application of comet assay in blood cells of Mediterranean loggerhead sea turtle (Caretta caretta). Marine Environmental Research 96, 68 -72.

Carballo, M.A., Mudry, M.D., 2006. Indicadores y Marcadores Biológicos. In: Mudry, M.D., Carballo, M.A. (Eds.), Genética Toxicológica, Editorial De los Cuatro Vientos. Buenos Aires, 83-107 
Collins, A. 2004. Comet Assay for DNA damage and repair: principles, applications and limitations. Mol Biotechnol; 26:249-61.

Collins, A., Azqueta, A., Brunborg, G., Gaivai, I., Giovannelli, I., Kruszewski, M., Smith, C., Stetina, R. 2008. The comet assay: topical issues. Mutagenesis vol. 23 no. 3 pp. $143-151$.

Crump, K.L., Trudeau, V.L., 2009. Mercury-induced reproductive impairment in fish. Environ. Toxicol. Chem. 28, 895-907.

De La Ossa, J., De La Ossa-Lacayo A. 2011. Cacería de subsistencia en San Marcos, Sucre, Colombia. Colombia. Revista Colombiana de Ciencia Animal 3 (2): 213-224.

De La Ossa-Lacayo, A., De La Ossa J. 2012. Índice de valor de uso para fauna silvestre en la región del San Jorge, Mojana sucreña, Colombia. Revista Colombiana de Ciencia Animal 4 (2): 308-319.

Di Giacomo, M., Comazzetto, S., Saini, H., De Fazio, S., Carrieri, C., Morgan, M., et al., 2013. Multiple epigenetic mechanisms and the piRNA pathway enforce LINE1 silencing during adult spermatogenesis. Mol. Cell 50, 601-608. 
Eggins, S; Schneider, L; Krikowa, F; Vogt, RC; Da Silveira; Maher, W, 2015. Mercury concentrations in different tissues of turtle and caiman species from the Rio Purus, Amazonas, Brazil. Environ. Toxicol and Chem. 34, 2771-2781

Frederick P, Jayasena N., 2011. Altered pairing behaviour and reproductive success in white ibises exposed to environmentally relevant concentrations of methylmercury. Proc R Soc Lond B 278:1851-1857.

Hopkins, W.A., 2000. Reptile toxicology: challenges and opportunities on the lastfrontier in vertebrate ecotoxicology. Environ. Toxicol. Chem. 19, 2391-2393.

Hopkins, W.A., 2007. Amphibians as models for studying environmental change. Inst. Lab. Anim. Res. J. 48(3), 270-277.

INGEOMINAS, 1995. Instituto de Investigaciones en Geociencias, Minería y Química. Minería de Oro. Ministerio de Minas y Energía, Bogotá, Colombia.

Jacobson, E.R. 1984. Immobilization, blood sampling, necropsy techniques, and diseases of crocodilians: a review. J Zoo Anim Med. 15(1):38-45.

Jagoe, C.H., Arnold-Hill, B., Yanochko, G.M., Winger, P.V., Brisbin Jr., I.L., 1998. Mercury in aligators (Alligator mississippiensis) in the southern United States. Sci. Total Environ. 213, 255-262. 
Khan, B., Tansel, B. 2000. Mercury bioconcentration factors in American alligators (Alligator mississippiensis) in the Florida Everglades. Ecotoxicol. Environ. Saf., 47: $54-58$.

Lázaro, W.L., de Oliveira, R.F., dos Santos-Filho, M., da Silva, C.J., Malm, O., Ignacio AR, et al., 2015. Non-lethal sampling for mercury evaluation in crocodilians. Chemosphere 138, 25-32.

Marrugo, J., Benitez, L., Olivero, J., Lans, E., Vasquez, F., 2010. Spatial and seasonal mercury distribution in the Ayapel Marsh, Mojana región, Colombia. Int. J. Environ. Health Res. 20, 451-459.

Marrugo, J., Benitez, L.N., Olivero-Verbel, J., 2008a. Distribution of mercury in several environmental compartments in an aquatic ecosystem impacted by gold mining in northern Colombia. Arch. Environ. Contam. Toxicol. 55 (2), 305-316.

Marrugo, J., Lans, E., Benítez, L., 2007. Finding of mercury in fish from the Ayapel Marsh, Colombia. Rev. MVZ Córdoba 12, 878-886.

Marrugo, J., Verbel, J.O., Ceballos, E.L., Benitez, L.N., 2008b. Total mercury and methylmercury concentrations in fish from the Mojana region of Colombia. Environ. Geochem. Health 30, 21-30. 
Marrugo-Negrete, J., Calao, C. 2015a. Efectos Genotóxicos asociados a metales pesados en una población humana de la región de La Mojana, Colombia, 2013. Revita Biomedica. Vol 35.

Marrugo-Negrete, J., Pinedo-Hernández, J., Díez, S. 2015b. Geochemistry of mercury in tropical swamps impacted by gold mining. Chemosphere 134, 44-51.

Meyer E, Eagles-Smith CA, Sparling D, Blumenshine S. 2014. Mercury exposure associated with altered plasma thyroid hormones in the declining western pond turtle (Emys marmorata) from California mountain streams. Environ Sci Technol 48:2989-2996.

Mitchelmore, C., Chipman, J., 1998. DNA strand breakage in aquatic organisms and the potential value of the comet assay in environmental monitoring. Mutat. Res. 399, 135-147.

Mitchelmore, C.L., Rowe, C.L., Place, A.R., 2006. Tools for assessing contaminant exposure and effects in reptiles In: Gardner, S.C., Oberdörster, E., (Eds.), Toxicology of Reptiles. Taylor \& Francis Group, CRC press, Boca Raton, USA, pp. $63-122$.

Morales-Betancour, M., Lasso, J. De La Ossa V., Fajardo, P. 2013. VIII. Biología y conservación de los Crocodylia de Colombia. Serie Editorial Recursos Hidrobiológicos y Pesqueros Continentales de Colombia. Instituto de Investigación 
de Recursos Biológicos Alexander von Humboldt (IAvH). Bogotá, D. C., Colombia, $336 \mathrm{pp}$.

Nilsen, F. M.; Parrott, B. B.; Bowden, J. A.; Kassim, B. L.; Somerville, S. E.; Bryan, T. A.; Bryan, C. E.; Lange, T. R.; Delaney, J. P.; Brunell, A. M.; Long, S. E.; Guillete Jr, L. J. 2016. Global DNA methylation loss associated with mercury contamination and aging in the American alligator (Alligator mississippiensis). Sci. Tot. Environ., 545-546:389-397.

Olivero J, Johnson B, Argüello E. 2002. Human exposure to mercury in San Jorge river basin, Colombia (South America). Sci Total Environ. 289:41-7.

Olivero, J., Johnson, B., Mendoza, C. 2004. Mercury in the aquatic environment of the village of Caimito at the Mojana region, North of Colombia. Water Air Soil Pollut 159:409-20.

Olivero, J., Young, C.F., Caballero, G.K., 2014. Contaminación por mercurio en aire del distrito minero de San Martín de Loba en el Departamento de Bolívar, Colombia. Rev. Int. Contam. Ambie. 30, 7-10.

Parrott, B.B., Bowden, J.A., Kohno, S., JA, C.-M.C., Hale, M.D., Bangma, J.T., et al., 2014. Influence of tissue, age, and environmental quality on DNA methylation in Alligator mississippiensis. Reproduction (REP-13-0498). 
Perez-Vargas, H., Vidal, J., Marrugo, J. 2014. Evaluación de la capacidad acumuladora de mercurio del ají (Capsicum annuum). Rev. Salud pública, Volumen 16(6); 897-909.

Pinedo, J., Marrugo, J., Díez S. 2015. Speciation and bioavailability of mercury in sediments impacted by gold mining in Colombia. Chemosphere. 119:1289-95.

Poletta, G.L., Larriera, A., Kleinsorge, E., Mudry, M.D., 2008. Caiman latirostris (broad-snouted caiman) as a sentinel organism for genotoxic monitoring: basal values determination of micronucleus and comet assay. Mutat. Res. 650, 202-209.

Poletta, G.L., Larriera, A., Kleinsorge, E., Mudry, M.D., 2009. Genotoxicity of the herbicide formulation Roundups (glyphosate) in broad-snouted caimán (Caiman latirostris) evidenced by the Comet assay and the Micronucleus test. Mutat. Res. 672, 95-102.

Poletta, GL., Kleinsorge, E., Paonessa, A., Mudry, M.D., Larriera, A., Siroski, P.A., 2011. Genetic, enzymatic and developmental alterations observed in Caiman latirostris exposed in ovo to pesticide formulations and mixtures in an experiment simulating environmental exposure. Ecotoxicol. Environ. Saf. 74, 852-859.

Rainwater, T., Wu, T., Finger, A., Canas, J., Yu, L., Reynolds, K., Coiunbatore, G., Barr, B., Platt, S., Cobb, G., Anderson, T., and McMurry, S. 2007 Metals and 
organochlorine pesticides in the caudal scutes of crocodiles from Belize and Costa Rica. Sci. Total Environ., 373: 146-156.

Rainwater, T.R., Adair, B.M., Platt, S.G., Anderson, T.A., Cobb, G.P., McMurry, S.T., 2002. Mercury in Morelet's crocodile eggs from northern Belize. Arch. Environ. Contam. Toxicol. 42, 319-324.

Richardson, K., Webb, G., Manolis, S., 2002. Crocodiles: Inside Out: a Guide to the Crocodilians and Their Functional Morphology. Surrey Beatty and Sons, Ltd., Sydney, p. 172.

Rodríguez-Ferreiro, G., Cancino, L., López, M., Palermo, A., ansory, M., Prieto, E., Carballo, M. 2002. DNA single strand breaks in peripheral blood lymphocytes induced by three nitroimidazole derivatives. Toxicol. Lett. 132: 109-115.

Rodriguez, J., Frigola, J., Vendrell, E., Risques, R.A., Fraga, M.F., Morales, C., et al., 2006. Chromosomal instability correlates with genome-wide DNA demethylation in human primary colorectal cancers. Cancer Res. 66, 8462-9468.

Rodríguez, M. 1989. Tres modelos de crecimiento en longitud de neonatos y juveniles de Caiman crocodilus fuscus (Cope, 1968), (Crocodylia: Alligatoridae) en cautiverio. Trianea 3: 61-66. 
Schaumburg, L., Poletta, G., Mudry, M. 2012. Baseline values of Micronuclei and Comet Assay in the lizard Tupinambis merianae (Teiidae, Squamata). Ecotoxicology and environmental safety 84 (2012): 99-103.

Schneider, L., Eggins, S., Maher, W., Vogt, R.C., Krikowa, F., Kinsley, L., Eggins, S.M., Da Silveira, R., 2015. An evaluation of the use of reptile dermal scutes as a noninvasive method to monitor mercury concentrations in the environment. Chemosphere, (119); 163-170.

Schneider, L., Peleja, R.P., Kluczkovski, A., Freire, G.M., Marioni, B., Vogt, R.C., Silveira, R., 2012. Mercury concentrations in the spectacled caiman and black caiman (Alligatoridae) of the Amazon, implications for human health. Arch. Environ. Contam. Toxicol. 63, 270-279.

Singh, N.P., McCoy, M.T., Tice, R.R., Schneider, E.L. 1988. A simple technique for quantitation of low levels of DNA damage in individuals cells. Exp. Cell. Res. 175: 184-191.

Strunjak-Perovic, I., Lisicic, D., Coz-Rakovac, R., Topic Popovic, N., Jada, M., Benkovi, V., Tadic, Z., 2010. Evaluation of micronucleus and erythrocytic nuclear abnormalities in Balkan whip snake Hierophis gemonensis. Ecotoxicology 19, 4601465. 
Tellez, M., B. Arevalo, I. Paquet-Durand, and Shawn Heflick. 2017. Population status of Morelet's Crocodile (Crocodylus moreletii) in Chirquibul Forest, Belize. Mesoamerican Herpetology 4: 8-21.

Tice, E., Agurell, D., Anderson, B., Burlinson, A. Hartmann, H., Kobayashi, Y., Miyamae, E. Rojas, J., Ryu, Y. 2000. Single cell gel/comet assay: guidelines for in vitro and in vivo genetic toxicology testing, Environ. Mol. Mutagen. 35;206-221.

UPME-MME-UC, 2015. Unidad de Planeación Minero Energética, Ministerio de Minas y Energía, Universidad de Córdoba. Incidencia real de la minería del carbón, del oro y del uso del mercurio en la calidad ambiental con énfasis especial en el recurso hídrico - diseño de herramientas para la planeación sectorial. Informe Técnico (Reporte Final). Bogotá D.C.

UPME-MME-UC, 2016. Unidad de Planeación Minero Energética, Ministerio de Minas y Energía, Universidad de Córdoba. Identificación y caracterización de Unidades Básicas de Beneficio Aurifero en 261 Municipios de Colombia. Informe Técnico (Reporte Final). Bogotá D.C.

Urbina-Cardona, J. N., E. A. Bernal, N. Giraldo-Echeverry y A. EcheverryAlcnedra. 2015. El monitoreo de Herpetofauna en los procesos de restauración ecológica: Indicadores y métodos. En: Aguilar-Garavito, M. Y W. Ramírez (Eds.). Monitoreo a procesos de restauración ecológica, aplicado a ecosistemas terrestre. 
Instituto de Investigaciones de Recursos Biológicos Alexander von Humboldt. Bogotá, D. C., Colombia.

USEPA. 2007. Method 7473. Mercury in solids and solutions by thermal decomposition, amalgamation, and atomic absorption spectrophotometry.

Valencia-Aguilar, A., A. M. Cortés-Gómez y C. A. RuizAgudelo. 2013. Ecosystem serviced provided by amphibians and reptiles in neotropical ecosystems. International Journal of Biodiversity science, Ecosystem services and Management 9 (3): 257-272.

Vanzolini, P.E., Nelson P. 1990. Manual de recolección y preparación de animales (2da. ed.). Facultad de Ciencias, UNAM, México.

Veiga, M.M., 1997. Introducing New Technologies for Abatement of Global Mercury Pollution in Latin America. UNIDO/UBC/CETEM, Rio de Janeiro.

Vidal, J.; Marrugo, J.; Pérez, L. 2010. Remediación de suelos contaminados con mercurio utilizando guarumo (Cecropia peltata). Ingeniería y Desarrollo. ISSN 0122-3461. Colombia.

Yanochko, G., Jagoe, C., Brisbin Jr., I. 1997. Tissue mercury concentrations in alligators (Alligator mississippiensis) from the Florida Everglades and the Savannah River Site, South Carolina. Arch. Environ. Contam. Toxicol. 32, 323328. 
Zapata, L., Bock, B., Palacio, J. 2016. Application of the micronucleus test and comet assay in Trachemys callirostris erythrocytes as a model for in situ genotoxic monitoring. Ecotoxicol Environ Saf.127:108-16.

Zuñiga, G., Torres, O., Zamora, A., Gomez, B., Ramos, M., Martınez, S. 2001. Differences in the number of micronucleated erythrocytes among Young and adult animals including humans. Spontaneous micronuclei in 43 species.Mutat. Res. 494, 161-167. 


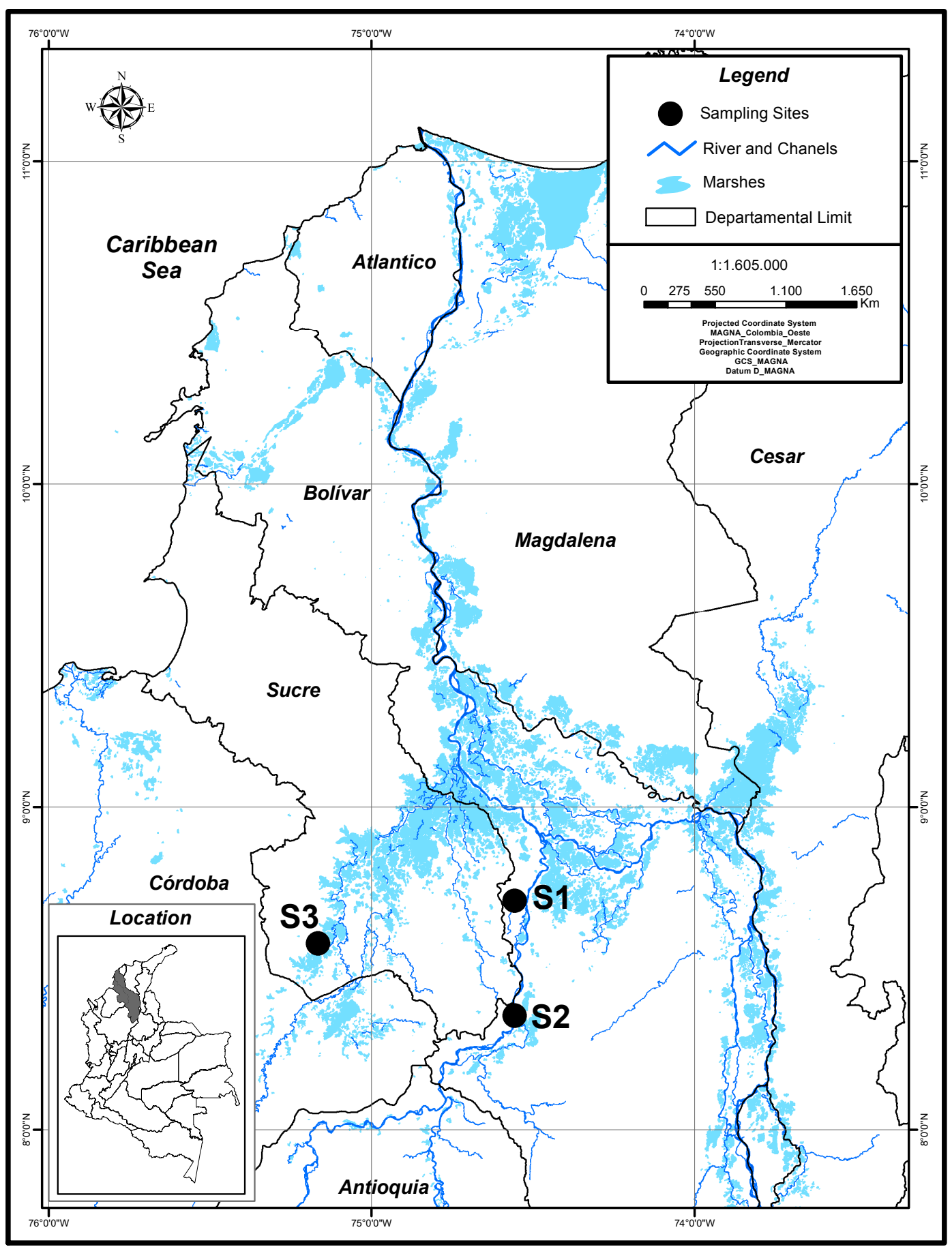

Figure 1. Map of the sampling sites location in La Mojana floodplain. La Redonda marsh (S1), and La Encaramada marsh (S2) are impacted by gold mining; S3 is the reference site 


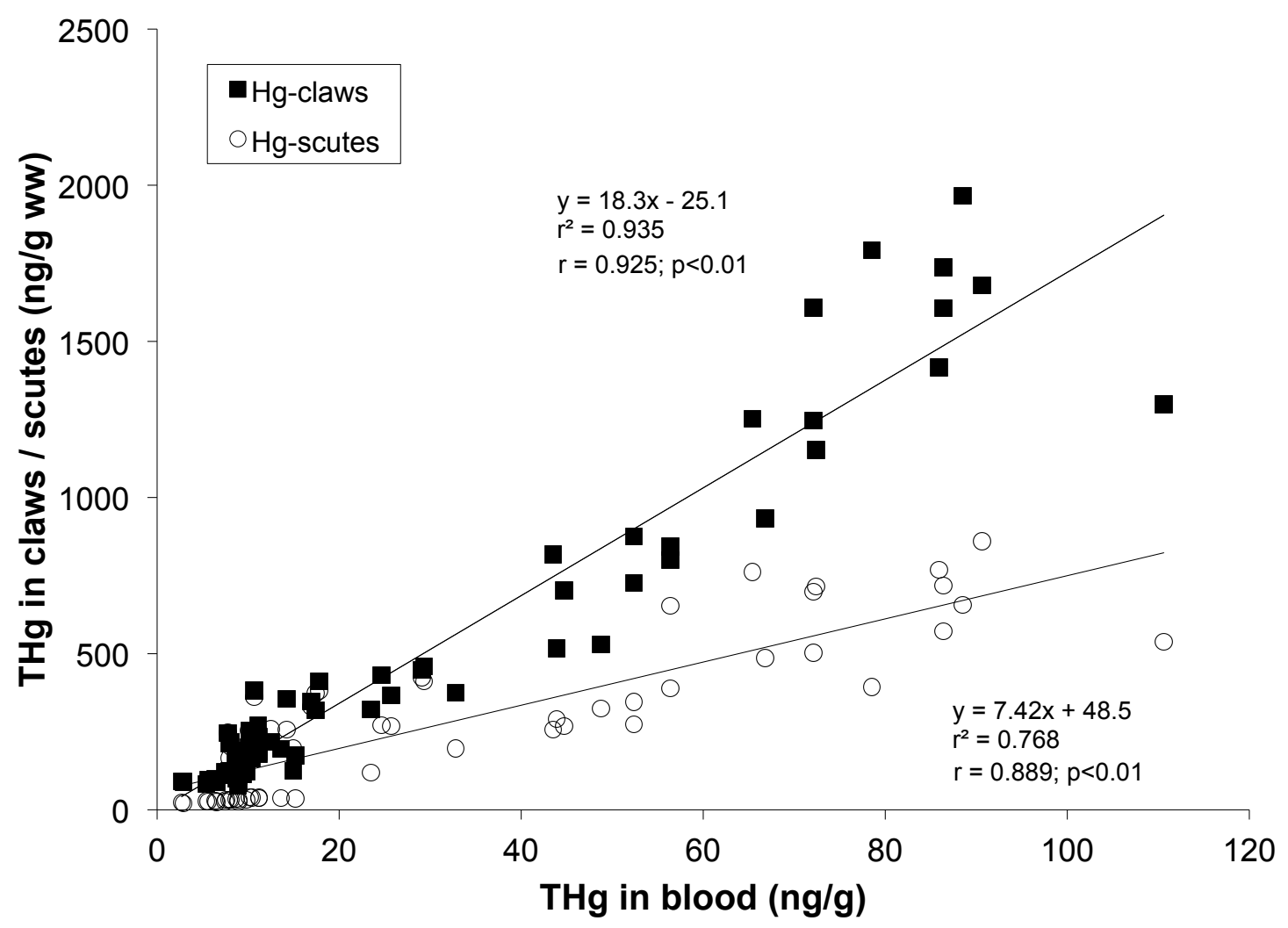

Figure 2. Correlation among THg concentrations in blood, claws and scales 


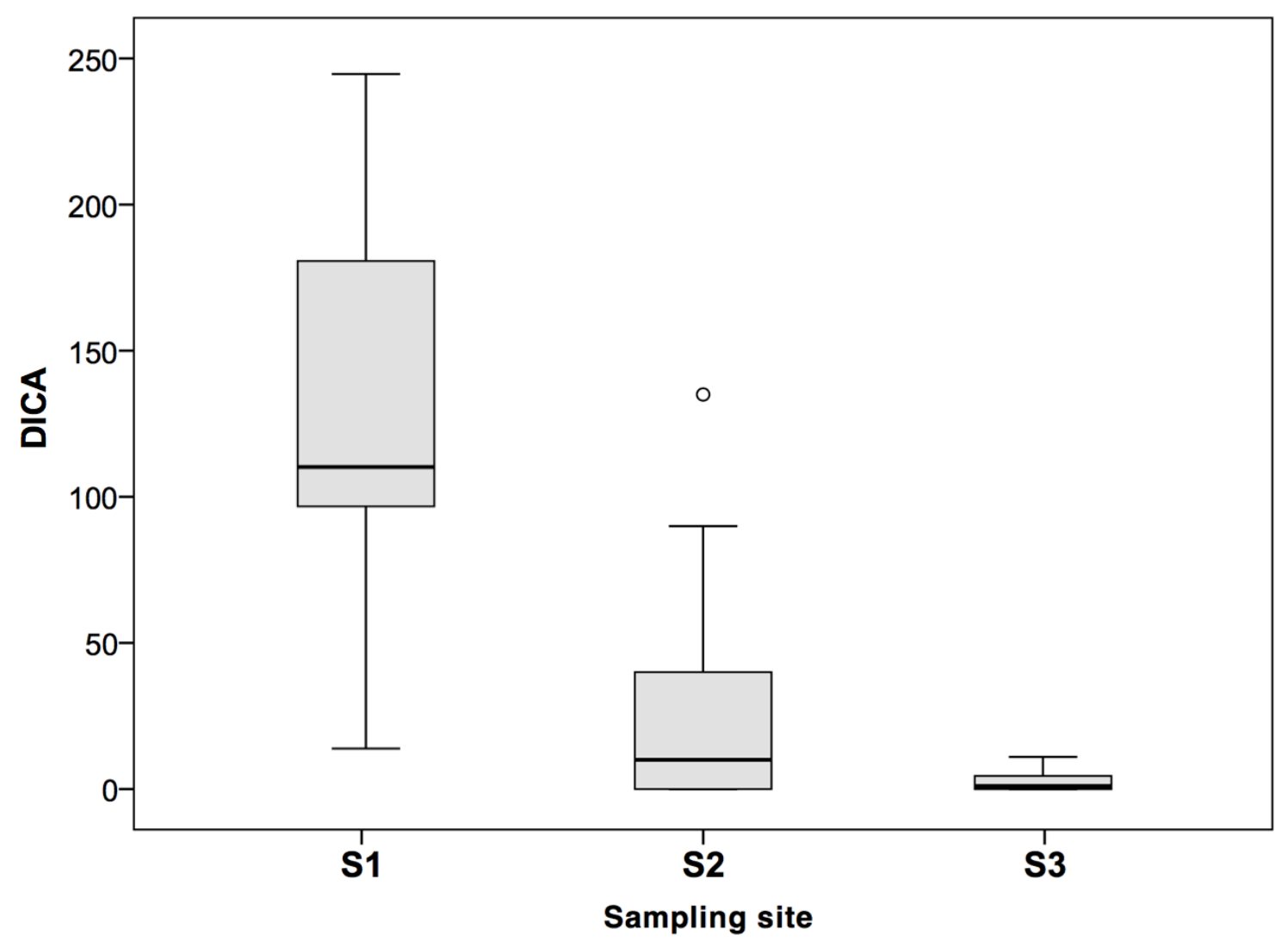

Figure 3. Damage Index Comet Assay (DICA) at the different samples sites. La Redonda marsh (S1) ( $n=23)$, and La Encaramada marsh (S2) $(n=22)$ are impacted by gold mining; S3 $(n=20)$ is the reference site. 
Table 1. Biometric values, sex ratio, damage index comet assay (DICA), and total mercury ( $\mathrm{THg}, \mathrm{ng} / \mathrm{g} \mathrm{ww}$ ) concentrations in blood, claws and caudal scutes of $\mathrm{C}$. crocodilus fuscus captured in La Mojana floodplain, Colombia. Mean values \pm standard deviation.

\begin{tabular}{ccccccccc}
\hline Site & $N$ & Weight $(g)$ & Length $(\mathrm{cm})$ & Sex Ratio (F:M) & Hg-blood & Hg-claw & Hg-scute & DICA \\
\hline S1 & 22 & $468 \pm 49^{A}$ & $57.2 \pm 3.5^{B}$ & $2: 1$ & $65.0 \pm 21.6^{\mathrm{a}}$ & $1100 \pm 492^{\mathrm{d}}$ & $490 \pm 216^{\mathrm{g}}$ & $134 \pm 63$ \\
\hline S2 & 23 & $5448 \pm 172^{\mathrm{A}}$ & $57.5 \pm 6.8^{\mathrm{B}}$ & $3: 2$ & $14.1 \pm 6.9^{\mathrm{b}}$ & $267 \pm 117^{\mathrm{e}}$ & $247 \pm 98^{\mathrm{e}}$ & $25 \pm 38$ \\
S3 & 20 & $496 \pm 13^{\mathrm{A}}$ & $59.0 \pm 1.6^{\mathrm{B}}$ & $2: 3$ & $8.4 \pm 3.1^{\mathrm{C}}$ & $131 \pm 38^{\mathrm{f}}$ & $31.5 \pm 5.8^{\mathrm{h}}$ & $5 \pm 3$ \\
\hline
\end{tabular}

Different uppercase letters represent differences in size (weight and length) for the different sampling sites. Different lowercase letters represent significant differences in THg content between sites and tissues. 
Table 2. $\mathrm{THg}$ (ng/g, ww) from different species of alligators and caimans worldwide in different tissues

\begin{tabular}{|c|c|c|c|c|c|}
\hline Species & THg & $\mathbf{N}$ & Tissue & Location & Reference \\
\hline \multirow[t]{2}{*}{ A. mississippiensis } & $56 \pm 13$ & 31 & skin & Florida, USA & Burger et al. (2000) \\
\hline & $1012 \pm 741$ & 13 & keratin & Amazonia, Brazil & Schneider et al. (2015) \\
\hline C.crocodilus & $882 \pm 564$ & 7 & keratin & Amazonia, Brazil & \\
\hline C.yacare & $96 \pm 92$ & 17 & scutes & Paraguay river Pantanal, Brazil & Lazaro et al, 2015 \\
\hline C.yacare & $846 \pm 623$ & 17 & claws & Paraguay river Pantanal, Brazil & \\
\hline C.yacare & $264 \pm 159$ & 22 & scutes & Bento Gomes river Pantanal, Brazil & \\
\hline C.yacare & $1945 \pm 704$ & 22 & claws & Bento Gomes river Pantanal, Brazil & \\
\hline C.crocodilus & $60 \pm 63$ & 11 & blood & Puris river, Amazonia, Brazil & Eggins et al., 2015 \\
\hline C.crocodilus & $3527 \pm 3095$ & 8 & keratin & & \\
\hline M.niger & $48 \pm 32$ & 12 & blood & & \\
\hline M.niger & $2092 \pm 1052$ & 13 & keratin & & \\
\hline P.unifilis & $4 \pm 10$ & 18 & blood & & \\
\hline P.unifilis & $148 \pm 70$ & 9 & keratin & & \\
\hline P.expansa & $1 \pm 1$ & 5 & blood & & \\
\hline P.expansa & 169 & 1 & keratin & & \\
\hline C.crocodilus & $39 \pm 30$ & 45 & blood & Impacted areas, La Mojana,Colombia & Present study \\
\hline C.crocodilus & $674 \pm 547$ & 45 & claws & & \\
\hline C.crocodilus & $366 \pm 205$ & 45 & scutes & & \\
\hline C.crocodilus & $8 \pm 3$ & 20 & blood & Control site, La Mojana, Colombia & Present study \\
\hline C.crocodilus & $130 \pm 38$ & 20 & claws & & \\
\hline C.crocodilus & $32 \pm 6$ & 20 & scutes & & \\
\hline
\end{tabular}




\section{SUPPLEMENTARY INFORMATION}
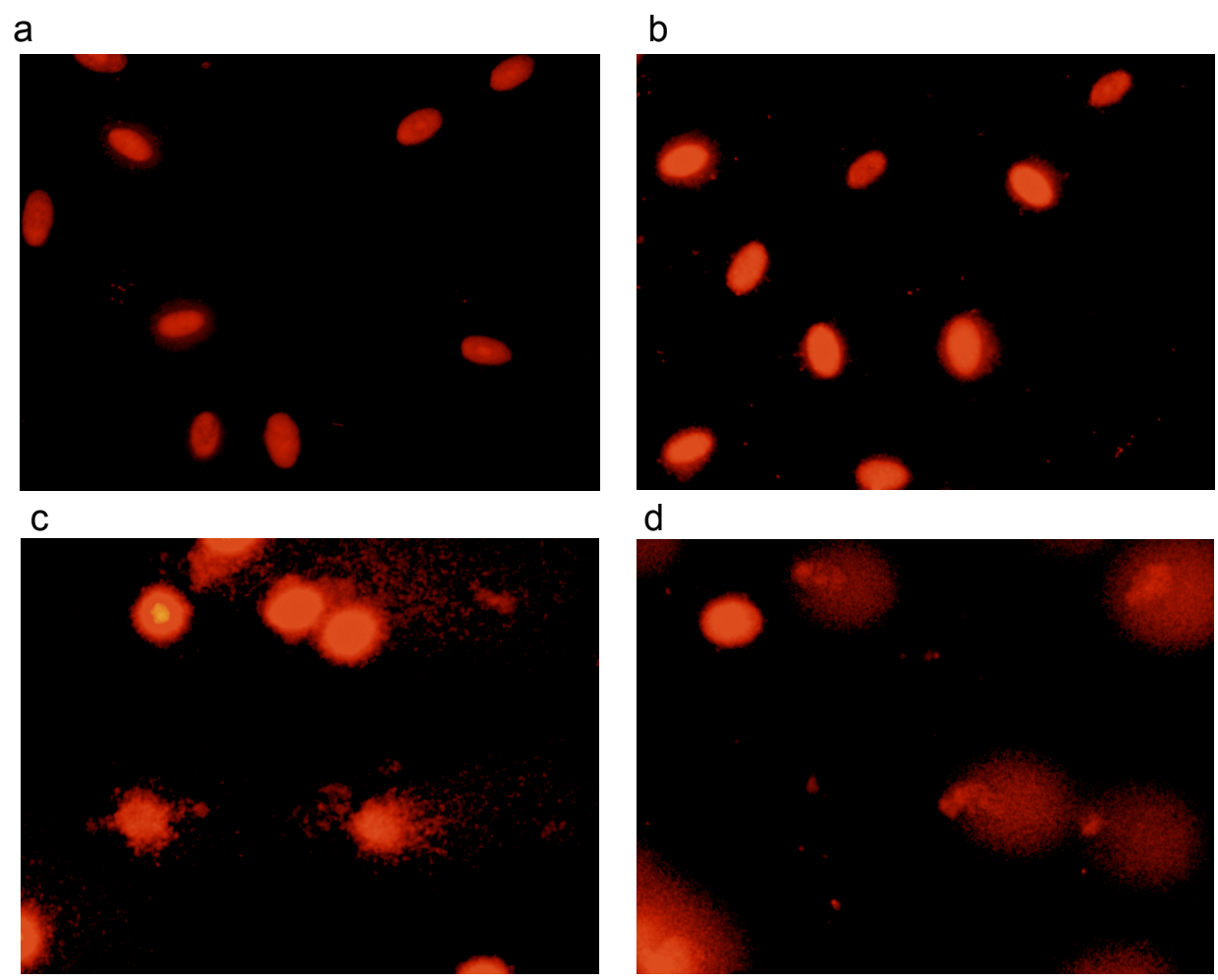

Figure SI. Comet assay images of different damage classes obtained from the peripheral blood of the crocodilians. (a) No obvious damage Class 0; (b) Damage at the cellular level class 0 and 1; (c) Damage at the cellular level Class 3 and 4; (d) Damage at the cellular level Class 4 